\title{
INVESTIGATION OF METALS REMOVAL WITH CHLORELLA ESP-6 MICROALGAE IN METAL SECTOR WASTEWATER
}

\author{
Hilal Şen ${ }^{1}$, Kadriye Oktor ${ }^{*}$ \\ ${ }^{1}$ Environmental Engineering, Faculty of Engineering, University of Kocaeli, Kocaeli, Turkey; \\ "Correspondent Author Kadriye Oktor, email: koktor@ hotmail.com; oktor@kocaeli.edu.tr;
}

Received August 2019; Accepted September 2019; Published October 2019;

DOI: https://doi.org/10.31407/ijees9406

\begin{abstract}
In this study,with microalgae the biodegradability of metals were investigated in the metal industry wastewater. The wastewater used in the study were supplied from a company which is engaged in metal preparation, processing, galvanizing operations in province Kocaeli of Turkey. Wastewater samples were diluted $0 \%-10 \%-20 \%$ by volume in the laboratory. Chlorella Esp-6 were sown as a solid culture in the diluted wastewater samples. Then, the removal of $\mathrm{Zn}, \mathrm{Fe}, \mathrm{Mg}, \mathrm{Ca}, \mathrm{Al}, \mathrm{Na}$ and $\mathrm{K}$ metals was observed. During the cultivation of microalgae, samples were taken from the wastewater samples on the $1^{\text {st }}, 7^{\text {th }}$ and $24^{\text {th }}$ days. The removal was observed to have the highest efficiency at different dilution rates on $1^{\text {st }}$ day and $24^{\text {th }}$ day of the study. Removal efficiencies of $\mathrm{Zn}$ (20\% dilution, $24^{\text {th }}$ day), Fe ( $20 \%$ dilution, $24^{\text {th }}$ day), $\mathrm{Mg}$ ( $10 \%$ dilution, $24^{\text {th }}$ day), $\mathrm{Ca}$ (20\%dilution, $1^{\text {st }}$ day), $\mathrm{Al}$ ( $10 \%$ dilution $24^{\text {th }}$ day), $\mathrm{Na}(0 \%$ dilution, $1^{\text {st }}$ day) and $\mathrm{K}\left(20 \%\right.$ dilution, $24^{\text {th }}$ day) were calculated as $97.51 \%, 97.12 \%, 70.69 \%, 99.06 \%, 87.20 \%$, $90.05 \%, 37.46 \%$, respectively. Based on the calculated results, it has been observed that removal of metal with microalgae in metal sector wastewater can be applied as an alternative treatment method.
\end{abstract}

Keywords: Wastewater Treatment, Metal Removal, Metal Industry, Microalgae 